\title{
Improvement of Classroom Management Skills of Teachers Leads to Creating Positive Classroom Climate
}

\author{
Damla GÜZELDERE AYDIN¹, Şakire OCAK KARABAY²
}

\section{ARTICLE INFO}

Article History:

Received 14.05.2019

Received in revised form

14.11.2019

Accepted

Available online

01.01.2020

\begin{abstract}
This study aims to evaluate the effects of "Classroom Management Training Programme" on preschool teachers' teaching styles regarding classroom management practices and children's behaviors in the classroom atmosphere. For this study, thirty teachers were selected from the schools in İzmir by convenience sampling method. In this quasi-experimental study with a pre-test intervention - post-test design, data was collected thorough Teaching Style Rating Scale (TSRS), Classroom Atmosphere Rating Scale (CARS) and Semi-structured Interview Form. According to the findings, the exprimental teachers performed better on problem solving, preventing misbehaviours, classroom management, and applying discipline. Children in in the experimental group were more positive, cooperative and adoptive rather than disruptive compared to control group's children in the classroom atmosphere. Moreover the teachers expressed that they preferred more to use preventive and supportive approach rather than restrictive approach to cope with undesirable behaviors.selected from the schools in İzmir by convenience sampling method. In this quasiexperimental study with a pre-test - intervention - post-test design, data was collected thorough Teaching Style Rating Scale (TSRS), Classroom Atmosphere Rating Scale (CARS) and Semistructured Interview Form. According to the findings, the exprimental teachers performed better on problem solving, preventing misbehaviours, classroom management, and applying discipline. Children in in the experimental group were more positive, cooperative and adoptive rather than disruptive compared to control group's children in the classroom atmosphere. Moreover the teachers expressed that they preferred more to use preventive and supportive approach rather than restrictive approach to cope with undesirable behaviors.This study aims to evaluate the effects of "Classroom Management Training Programme" on preschool teachers' teaching styles regarding classroom management practices and children's behaviors in the classroom atmosphere. For this study, thirty teachers were selected from the schools in İzmir by convenience sampling method. In this quasi-experimental study with a pre-test - intervention - post-test design, data was collected thorough Teaching Style Rating Scale (TSRS), Classroom Atmosphere Rating Scale (CARS) and Semistructured Interview Form. According to the findings, the exprimental teachers performed better on problem solving, preventing misbehaviours, classroom management, and applying discipline. Children in in the experimental group were more positive, cooperative and adoptive rather than disruptive compared to control group's children in the classroom atmosphere. Moreover the teachers expressed that they preferred more to use preventive and supportive approach rather than restrictive approach to cope with undesirable behaviors. This study aims to evaluate the effects of "Classroom Management Training Programme" on preschool teachers' teaching styles regarding classroom management practices and children's behaviors in the classroom atmosphere. For this study, thirty teachers were
\end{abstract}

(C) IJERE. All rights reserved

Keywords: ${ }^{3}$

Preschool Education, Classroom Management, Early Childhood Teacher, Classroom Atmosphere

\section{INTRODUCTION}

Primary interactions of children in the classroom environment with their teachers leave permanent traces. At this point, the educator should be a role model for the children, and provides opportunities in order to develop positive relationships within the classroom. It is known that child-teacher relationships have protective functions (Sabol and Pianta, 2012) that eliminate or prevent misbehaviors by maintaining supervisory role in the classroom (Cartleoge and Kourea, 2008; Gartrell, 2001). In this process, teacher's classroom management approaches become crucial so that the classroom atmosphere grows into a setting environment that is secure, peaceful, interactive, and supportive for learning (Sieberer-Nagler, 2016; Sutton, 2004). According to Evertson, Emmer, and Worsham (2003, p. 176), teachers' choosing a strategy that has the

\footnotetext{
${ }^{1}$ damla.aydin@kavram.edu.tr, Izmir Kavram Vocational School, orcid.org/0000-0001-5618-1224

2 sakire.ocak@ege.edu.tr, Ege University, orcid.org/0000-0003-2240-0251
} 
least negative impact on children and that is the most effective impact on their misbehaviors is a general approach. Teachers need a variety of classroom management strategies that will meet children's needs and ensure that children develop appropriate manners and attitudes (Harlan and Rowland, 2002, p. 184; Jones and Jones, 2004, p. 7). Although these management strategies are various and in different dimensions, there is no single model or strategy for all children that will be successful in preventing misbehaviors, which sometimes complicates teachers' choices. While one dimension extends to the approaches (harsh, punishing, reactive, restrictive) that hurt child's faith in not only oneself but also in others, the other dimension covers the responsive approaches (supportive, preventive) that build confidence in themselves and others. The literature indicates that for enabling classroom management and preventing misbehaviours, teachers use reactive, supportive or proactive strategies such as giving verbal instructions, warning child by lowering to eye level, helping physically, defining and reminding clear and understandable rules, talking supportively, explaining the outcomes of behaviours, providing positive support, offering choices, sending time-out, using reward, reprimanding and punishing (Drang, 2011; Reddy, Fabiano, Dudek and Hsu, 2013; Ritz, Noltemeyer, Davis and Green, 2014; Ross, Little and Kienhuis, 2008; Rydell and Henricsson, 2004). Researchers express that it is very difficult to remove all problematic situations in the classroom by using only one classroom management model and therefore, teachers are required to choose and implement among various classroom management models by adapting the ones that are suitable to their expectations (Borich, 2007, p, 201; Demirtaş, 2012, p. 21). If teachers create a supportive climate in the classroom and prefer preventive and supportive approaches that will help to meet children's emotional needs and to form self-regulation skills, that would be an effective way in terms of classroom management strategies. It is known that supportive classroom environments increase positive child-teacher relationships and decrease behavioural problems (Howes et al., 2013). Additionally, it is underlined that teachers pay attention not to prefer punitive, reactive, restrictive, repressive approaches that will cause children to live through unhappy experiences (Emmer and Stough, 2001; Tillery, Varjas, Meyers and Collins, 2010).

On the other hand, Rogoff (1990) emphasizes that teachers should have an effective interaction with children in which they must make an effort so as to transfer knowledge, to develop their skills, to enrich their abilities related to academic performance (see Pianta, 2017, p.81). In this context, it is expressed that the strategies that teachers prefer to use and their professsional equipment considering classroom management have a critical impact on actualization of education effectively. Teachers who use classroom management strategies through supportive, intimate, warm and sensitive relationships can enable children to develop positive responses against school (Rimm-Kaufmann et al., 2002). Thus, Harlan and Rowland (2002, p, 44) state that the researches which reveal how important positive school and classroom climate is in promoting success and developing proper behaviours of children increase continuously. Increasing teachers' awareness how to manage children's misbehaviours in classroom would save the time spent in managing behaviour problems while the time spent for education activities and positive teacher-child relationships would increase (Jones and Jones, 2004, p, 78; Little, Hudson and Wilks, 2002). Thus, the time dedicated to education is used more effectively by preventing misbehaviours, and would lead to increase in school success of children (Webster-Stratton and Herman, 2010; Webster-Stratton, Reid and Hammond, 2004). In other studies it was also emphasized that teachers should be trained for improving their knowledge and skills related to classroom management (Drang, 2011; Emmer and Stough, 2001; Hickey et al., 2015; Ritz et al., 2014; Stough, Montague, Jo-Landmark and Williams-Diehm, 2015; Tillery et al., 2010).

Additionally, trial of different classroom management techniques by comparing each others gains importance to evaluate influence level over children and teachers. The results of these researches would be helpfull for teachers to decide which methods and techniques would be suitable for children's needs. For that reason, the findings of previous research will be informative about innovative classroom management approaches for meeting today's requirements. It will enable suitable approaches to become widespread by leading to new implementations in classroom practices for contributing teachers' management skills. However, it is also important to realize that teachers may not have enough knowledge about which of these strategies would increase quality of classroom climate and daily schedule (Allen, 2010; Drang, 2011; Kaya, Lundeen and Wolfgang, 2010). It is thought that the teachers working in the field may need training to increase their skills on preventive and responsive approaches so that it would be possibleto prevent both teacher'sand children's negative emotions fromescalating and to improve classroom wide behaviours of 
Güzeldere Aydin ,D. \& Ocak Karabay,Ş. (2020). Improvement of classroom management skills of teachers leads to creating positive classroom climate. International Journal of Educational Research

children. If close and warm relationships are established between preschoolers and their teachers, children's attitudes would positively change towards school and this situation would lead child to see the teacher in her/his life as a source of support. Those efforts would also affect classroom climate (Pianta, 1998; Westman and Bergmark, 2014). Therefore, an overall improvement of classroom management skills of preschool teachers would be critical to create a positive classroom climate.

In this study, a teacher trainingn programme was improved to be implemented in preschool classrooms to meet requirements in preventive and supportive dimensions that will enrich preschool teachers' classroom management strategies. In this direction, the main purpose of this study is to investigate the effect of the Classroom Management Training Program on teaching styles of preschool teachers they display during classroom management. At the same time, it is aimed to reveal the effectiveness of that program for overall classroom climate. Within this point of view, we aimed to answer the question below in accordance with the main purpose of the research:

1. What is the effect of Classroom Management Training Programme on preschool teachers' classroom management skills and overall classroom climate?

We hypothesized that experimental group teachers will gain more supportive and preventive approaches towards children's needs than control group teachers. Furthermore, it is also expected that this approach will increase positive behaviors and interactions among children within the whole classroom.

\section{METHOD}

\section{Design of Research}

In this quasi-experimental research, to analyze research problems in more details, we conducted a field research in which quantitative and qualitative methods are combined together. In quantitative part of the research, pre-test - post-test control group design has been used to analyze the effectiveness of the training programme. In qualitative part of the research, a case study design was used to evaluate what kinds of approaches teachers have related to classroom management practices based onteachers' point of view.

\section{Participant Group}

A participant group consisting of 15 experimental and 15 control group teachers from three different preschools (two from Ege University Campus, one independent public preschool) in Izmir which is a metropolitan city on Aegean costof Turkey. Participants were included based on their willingness by using convenience sampling method. In these schools, the national preschool education program run by Ministry of is practiced as a full day program for preschool children. Two interviews before which volunteers were informed about the research were held with teachers and managers of preschool institutions that were planned to participate in the research in Autumn/Fall Semester of 2016-2017. All of the participants of these interviews are female and have graduated from child development and/or preschool teaching programs . The average age of experimental group teachers was 32 and it was 39 for control group teachers. The experience of teachers were ranging between $10-13$ years.

\section{Classroom Management Training Programme}

In this research, the researcher as being an expert in preventive intervention programs (Promoting Alternative Thinking Strategies / PATHS Preschool Curriculum, I Can Problem Solve and Second Step) evaluated commonly used classroom management methods and preventive intervention programmes in order to prepare this training program. The framework of this programme was based on strategies and the programmes that strengthen child-child and teacher-child relationships for enriching classroom climate and classroom management in preschool period. It was also developed in such a way to cover preventive and supportive dimensions in classroom management. It was predicted that this programme could deepen the connections that teacher will establish with children. By using effective, functional, and preventive classroom management approaches it would be possible to increase the outcomes related to enrichment of relationships. This training programme consists of two dimensions, classroom management and preventive 
intervention approaches. The first dimension of the training programme covers effective communication, discipline and classroom management strategies in preschool period. In the second dimension, the introduction of the beyond time out strategies and turtle techniques, and common features of widely used preventive intervention programmes were included.

In the first dimension of training programme, the importance and the necessity of the classroom management was explained to the teachers to create a positive and effective classroom atmosphere and to strengthen child-teacher relationships. Through this viewpoint, the teachers were equipped with different supportive and preventive techniques that improve the quality of child-teacher relationships. The researcher and the teachers analyzed classroom management strategies (responsive, restrictive, supportive and preventive strategies) to prevent or reduce misbehaviours likely to arise in classrooms. Moreovereffective classroom management techniques were explained to the teachers. Each strategy has been discussed and evaluated in detail concerning how it supports relationships in either positive or negative way. In order to achieve this, sample video clips and case studies related to the attitudes strengthening child - teacher relationships or vice-versa were presented and discussion sessions were held and critical feedbacks were shared with teachers.

In the second dimension of training programme, basic characteristics of preventive intervention programmes such as "I Can Problem Solve", "Promoting Alternative Thinking Strategies Curriculum" used widely in preschool education were introduced. The main objectives of these programmes were underlined and explained in order to reveal why preventive intervention programmes are required. Teachers are trained about how to enrich daily schedule in the preschool classroom including the content such as emotions, alternative problem solving and consequential thinking. Moreover, teachers' approaches towards children during problems and problem solving dialogues are also discussed. Teachers are taught Turtle Technique for body relaxation of children during crisis.

\section{Materials}

\section{Classroom Atmosphere Rating Scale (CARS)}

Classroom Atmosphere Rating Scale (CARS) was developed by Conduct Problems Prevention Research Group (1999) and adapted to Turkish by Arda (2011). This scale consists of ten items and has three dimensions: "Disruptive Behavior and Compliance", "Cooperation, Communication and Problem-Solving", "Classroom, Interest Level, Focus, Responsiveness". These dimensions evaluate children's level of compliance, cooperation, and interest/enthusiasm/involvement, how children obey classroom rules, solve their problems, and express their feelings. Samples of the scale item; students seem to handle transitions well, students consistently follow rules appropriate to settings, students attempt problem-solving.

The instrument also evaluates teacher's responsiveness to student's needs and feelings. Each item in the scale was coded from 1 (very high) to 5 (very low). If the coders observed less than 10 minutes because of conditions of classroom settings, they scored 6 (not-applicable to code). In a Turkish sample, the CARS showed adequate inter-rater reliability $\left(\mathrm{ICC}=.99^{* *},{ }^{* *} \mathrm{p}<.01\right)$ and good internal consistency (Cronbach's alpha: .99) (Arda, 2011, p. 86). In the present study, internal inter-rater reliability was adequate (ICC=.99). In another study, the reliability of the scale was assessed as $>.90$ in all dimensions except classroom interest level and enthusiasm dimensions (Cronbach's alpha: .77) (Baker-Henningham, Walker, Powell and Gardner, 2009).

The scale was applied by the researcher both before the training programme started and after the training programme ended. The researcher conducted 30-minute classroom observations (20 minute observation and 10 minute coding) for two times during structured activities and free play time.

\section{Teaching Style Rating Scale (TSRS)}

The scale was originally developed by Domitrovich, Cortes and Greenberg (2000) and adopted into Turkish by Arda (2011). It is 5 item likert-type scale that consists of 12 items and 5 dimensions: "Classroom Structure and Management", "Discipline", "Emotional Communication and Support", "Social Awareness and Problem Solving", "Preventing Misbehaviour" (Arda, 2011, p.87). Samples of the scale item; Consistency/Routine: Teacher has a regular routine in the classroom, keeps the rules the same from day to 
Güzeldere Aydin ,D. \& Ocak Karabay,Ş. (2020). Improvement of classroom management skills of teachers leads to creating positive classroom climate. International Journal of Educational Research

day, and is consistent in the way he/she responds to behavior problems in the classroom. Control/Limitsetting: Teacher sets reasonable limits on the children's behavior. He/she provides simple, clear, and positively stated directions when necessary but does not overly-control or restrict children.

In Turkey, Cronbach's Alpha for interrater reliability was reported: for "Structure and Management of Classroom" sub-dimension.97; for "Discipline sub-dimension.96; for "Emotional Communication and Support" sub-dimension.96; for "Social Awareness and Problem Solving" sub-dimension.98; for "Preventing Misbehaviour" subdimension. 98 and the correlation coefficient for interrater reliability was indicated as $.99^{* *}$ $\left({ }^{* *} \mathrm{p}<.01\right)($ Arda, 2011, p.88).

TSRS was applied before and after training programme and the observations were conducted for two times within 30-minute cycle (first 20 minutes for observation, 10 minutes for coding) during structured activities and free playtime.

\section{Semi-Structured Interview Form for Teachers}

In this research, we also used interviews in which it would possible to learn about deep information about perceptions, lives and thoughts of people (Büyüköztürk et al., 2016, Christensen, Johnson ve Turner, 2015). Draft questions related to subject were formed by examining the literature. Necessary modifications and arrangements were implemented in the direction of the feedbacks of two experts who are specialists in the field of child-teacher relations, preventive intervention programmes, and classroom management approaches in preschool period.

Three questions were designed to reveal teachers' classroom management strategies which teachers preferred to use to deal with children (What strategies do you use to ensure classroom management?, What is the time-out?, How do you implement a time-out?, etc.). Each question was enriched by probes designed to be open ended so that they would gather rich data.

\section{Data Collection Process}

After legal permissions were obtained from the institutions (Ege University and Turkish Ministry of Education), the school directors and the volunteer teachers were informed about the aims of the research and content of the training programme. The researcher determined the date and the time by coordinating with teachers for interviews and classroom observations. Additionally the teachers were requested to fill out the teacher information form. During pre-test step, observations were made by the researcher through TSRS and CARS . Classrooms and teachers were observed twice on different days in order to increase observation reliability. The researcher did not interrupt teacher's and children's activities and kept silence in one of the corners of the classrooms during observations. During observations, the teachers were interviewed individually and simultaneously at their free times so that it did not block the research and daily schedule. The interviews with the teachers were conducted approximately 20-30 minutes in silent places in their preschools. Data were recorded by taking notes without giving feedback by the researcher during the interviews.

After the completion of pre-test phase, training schedule was decided with the experimental group teachers. Classroom management training was given to the experimental group teachers for four hours a day and twice a week duringone month period. Trainings were conducted at the university, Faculty of Education by both researcher and an expert who prepared this training programme. The trainings were given either children were sleeping or they were in drama, ballet lessons not to hinder daily schedule in the schools. After the training programme was implemented, the teachers were given two months to reflect the principles, strategies of the training within daily schedule. At the end of this period, the observations and interviews were conducted for completing the post-test phase.

\section{Data Analysis}

The quantitative data obtained from both groups by using CARS and TSRS were analyzed by using SPSS 15.0 software. In order to examine the normality assumption of the data, Kolmogorov-Smirnov's test of normality was applied related the scales. According to normality tests, "Independent Samples t-test" and 
"Mann Whitney U Test" were used in inter-groups comparison, and "Dependent Samples t-test" and "Wilcoxen Signed Rank Test" were used in group comparison.

In the analysis of qualititative data obtained via semi-structured interviewsfor teachers, content analysis was used. Moreover, the quantitative data was presented in the tables as frequencies.

\section{FINDINGS}

As a first step in this study in order to evaluate the effects of the program, pre-test scores of the experimental and the control groups were assessed using the TSRS and CARS. There were no statistically significant differences between the two groups in terms of all subscales and total scores. Therefore, in this section, the findings of the experimental and control groups were compared only for the post-test scores of the two scales.

\section{Quantitative Findings}

\section{Post-Test Scores of TSRS between Control and Experimental Groups}

Based on the results of normality tests, in the post-test comparison of TSRS of both groups; independent samples t-test was applied for the sub-dimensions of social awereness and problem solving, preventing misbehaviour, and for total scores as well. Mann-Whitney U Test was also applied for other subdimensions (structure and process of classroom, discipline), and emotional communication and support.

Table 1. Results of Independent Samples t-Test of TSRS based on Post-Test Scores

\begin{tabular}{ccccccccc}
\hline Groups & N & Mean & S & Df & t & P & \\
\hline Experimental & 15 & 46,53 & 3,57 & 20,87 & 4,909 & $0,000^{*}$
\end{tabular}

TSRS Total Score

\begin{tabular}{cccccccc} 
Control & 15 & 36,60 & 6,97 & & & \\
\hline Experimental & 15 & 7,57 &, 68 & 22,72 & 5,137 & $0,000 *$
\end{tabular}

TSRS Social Awareness and Problem Solving

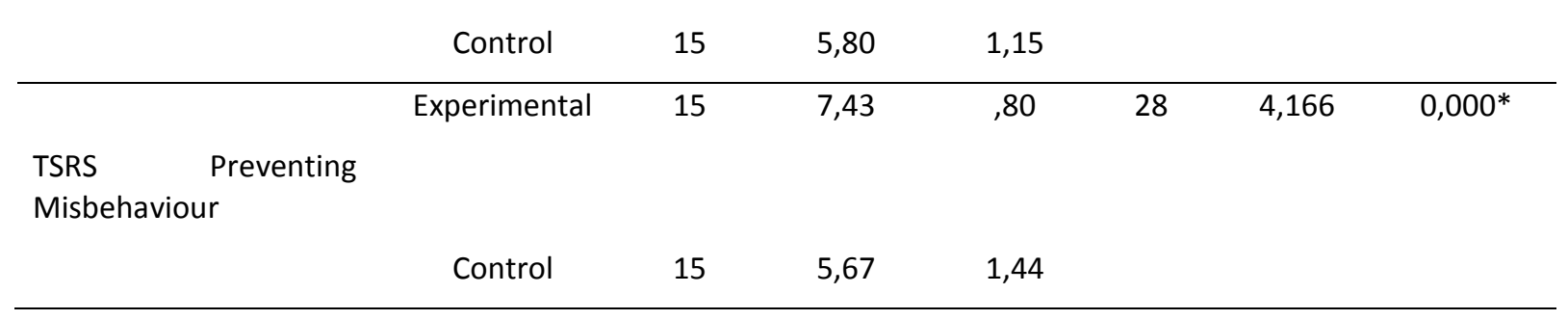

* Significance $\mathrm{p}$ for $\alpha=0,05$

Table 2. Results of Mann-Whitney U Test for TSRS based on Post-Test Scores

\begin{tabular}{lcccccc}
\hline & Groups & N & Ranks Mean & Ranks Total & U & P \\
\hline & Experimental & 15 & 21,47 & 322 & 23 & $0,000^{*}$ \\
$\begin{array}{l}\text { TSRS Classroom } \\
\text { Structure and } \\
\text { Management }\end{array}$ & & & & & & \\
& & & & & & \\
\hline & Control & 15 & 9,53 & 143 & & \\
\hline & Experimental & 15 & 21,43 & 321,5 & 23,50 & $0,000^{*}$
\end{tabular}




\begin{tabular}{lccccc}
\hline TSRS Discipline & & & & \\
& Control & 15 & 9,57 & 143,5 & \\
\hline & Experimental & 15 & 21,60 & 324 & 21 \\
TSRS Emotional & & & & \\
$\begin{array}{l}\text { Communication and } \\
\text { Support }\end{array}$ & & & & \\
& Control & 15 & 9,40 & 141 & \\
\hline
\end{tabular}

* Significance $\mathrm{p}$ for $\alpha=0,05$

Observations of the six -item TSRS Scale revealed a significant positive training impact. Five items as well as the total scale contributed to this impact. There was a significant effect favoring the experimental group on social awareness and problem solving, preventing misbehaviours, classroom structure and management, discipline and emotional communication and support, and also total test score. This difference is statistically at a significant level $(p=0,000<\alpha=0.05)$ for whole sub dimensions and total scores.

The findings in Table 1 and Table 2 support the hypothesis of "there will be a positive difference for the favor of experimental group between the scores of two groups".

\section{Post-Test Scores of CARS between Control and Experimental Groups}

According to the tests of normality in the analysis under this title, in post-test comparison of CARS of both groups; independent samples t-test was applied for the sub-dimensions of cooperation, communication and problem solving. Mann-Whitney $U$ Test was applied for the sub-dimensions of disruptive behaviour and compliance, classroom, interest level, focus, responsiveness and total points.

Table 3. Results of "Independent Samples t-test" for CARS based the post-test scores

\begin{tabular}{|c|c|c|c|c|c|c|c|c|}
\hline & & Groups & $\mathbf{N}$ & Mean & $\mathbf{S}$ & df & $\mathbf{T}$ & $\mathbf{P}$ \\
\hline & & Experimental & 15 & 6,43 & ,98 & 28 & -7.220 & $0,000^{*}$ \\
\hline \multicolumn{9}{|c|}{$\begin{array}{l}\text { CARS Cooperation, } \\
\text { Communication }\end{array}$} \\
\hline \multicolumn{9}{|l|}{$\begin{array}{l}\text { and } \\
\text { Solving }\end{array}$} \\
\hline & & Control & 15 & 9,37 & 1,23 & & & \\
\hline
\end{tabular}

* Significance $\mathrm{p}$ for $\alpha=0,05$

Table 4. Results of Mann-Whitney U Test for CARS based on post-test scores

\begin{tabular}{ccccccc}
\hline Groups & N & Ranks Mean & Ranks Total & U & P \\
\hline Experimental & 15 & 8,87 & 133 & 13 & $0,000^{*}$
\end{tabular}

CARS Total

\begin{tabular}{|c|c|c|c|c|c|c|c|}
\hline & & Control & 15 & 22,13 & 332 & & \\
\hline & & Experimental & 15 & 8,97 & 134,5 & 14,50 & $0,000 *$ \\
\hline \multirow{3}{*}{$\begin{array}{l}\text { CARS } \\
\text { Behaviour } \\
\text { Compliance }\end{array}$} & Disruptive & & & & & & \\
\hline & and & & & & & & \\
\hline & & Control & 15 & 22.03 & 330.5 & & \\
\hline
\end{tabular}




$\begin{array}{llllll}\text { Experimental } & 15 & 10,33 & 155 & 35 & 0,001^{*}\end{array}$

CARS Classroom, Interest Level, Focus, Responsiveness

Control $\quad 15 \quad 20,67 \quad 310$

* $\alpha=0,05$ için anlamlı $\mathrm{p}$ değeri

Observations of the four-item CARS Scale revealed a significant positive training impact on classroom atmosphere. Three items and the total test score contributed to this impact. There were significant effect favoring the experimental group on Cooperation, Communication and Problem Solving $(\mathrm{p}=0,000<\alpha=0.05)$, Disruptive Behaviour and Compliance and Classroom $(\mathrm{p}=0,000<\alpha=0.05)$, Interest Level, Focus, Responsiveness $(\mathrm{p}=0,001<\alpha=0.05)$ and total test score $(\mathrm{p}=0,000<\alpha=0.05)$.

When the results of Independent Samples t-Test and Mann Whitney U-Test were examined for CARS, these results in Table 3 and Table 4 support the hypothesis of "There will be a positive difference for the favor of experimental group between the scores of two groups.".

\section{Qualitative Findings}

Common categories of both groups were specified based on whole data after the data obtained from Semi-Structured Interview Form was listed separately for each question. The findings related to the classroom management skills of the teachers in experimental and control goups were specified depending on the main category that is Teachers' Classroom Management Approach Styles which was classified into three themes (supportive approach style, preventive approach style and restrictive approach style). These three themes were classified into sub-themes based on content analysis. At the same time, the findings gathered from the qualitative data were converted into the quantitative data set that reveals the teachers' classroom management approach styles.

The findings related to these three themes and their frequencies are presented in Table 5.

Table 5. The Findings Related to Classroom Management Approach Styles of the Teachers

\begin{tabular}{|c|c|c|c|c|}
\hline $\begin{array}{c}\text { Classroom Management Approach } \\
\text { Styles }\end{array}$ & $\begin{array}{c}\text { Experimental } \\
\text { Pre-test } \\
\text { (f) }\end{array}$ & $\begin{array}{c}\text { Experimental } \\
\text { Post-test } \\
\text { (f) }\end{array}$ & $\begin{array}{c}\text { Control } \\
\text { Pre-test } \\
\text { (f) }\end{array}$ & $\begin{array}{c}\text { Control } \\
\text { Post-test } \\
\text { (f) }\end{array}$ \\
\hline Supportive Approach Style & 48 & 69 & 64 & 54 \\
\hline Preventive Approach Style & 13 & 52 & 18 & 15 \\
\hline Restrictive Approach Style & 16 & 6 & 19 & 26 \\
\hline
\end{tabular}

The teachers in both groups mentioned about three types of approaches that are Supportive Approach Style, Preventive Approach Style, and Restrictive Approach Style as classroom management approach style.

When expression frequencies related to the teachers' approach styles in both groups were compared in pre-test and post-test phases, it was detected that the teachers in experimental group used supportive and preventive aproach styles more frequently in post-test in comparison to the pre-test. Additionally, the implementation of restrictive approach styles of the teachers in experimental group decreased after the training programme.

These findings indicate that classroom management training programme increases the experimental teachers' skills on classroom management. The teachers prefer to use more frequently the supportive and preventive approaches rather than the restrictive approach. These results support the hypothesis "Classroom management training program leads to a positive difference for the favor of the teachers in experimental group when classroom management approach styles of the teachers in experimental and control groups are compared." 
When the supportive approach styles of the teachers in both groups were analized, eight sub-themes and their frequencies were detected as shown in Table 6. It was observed that the teachers prefer to use these sub-themes to establish classroom management.

Table 6. The Findings Related to Supportive Approach Styles of Teachers

\begin{tabular}{|c|c|c|c|c|}
\hline Supportive Approach Style & $\begin{array}{c}\text { Experimental } \\
\text { Pre-test } \\
\text { (f) }\end{array}$ & $\begin{array}{c}\text { Experimental } \\
\text { Post-test } \\
\text { (f) }\end{array}$ & $\begin{array}{l}\text { Control } \\
\text { Pre-test } \\
\text { (f) }\end{array}$ & $\begin{array}{c}\text { Control } \\
\text { Post-test } \\
\text { (f) }\end{array}$ \\
\hline Calming/Time Out & 19 & 8 & 22 & 17 \\
\hline Awarding & 13 & 15 & 11 & 4 \\
\hline Giving Role/Responsibility & 6 & 7 & 5 & 3 \\
\hline Giving Explanation Related to Behaviour & 3 & 21 & 12 & 18 \\
\hline Drawing Attention & 2 & 6 & 5 & 3 \\
\hline Example Case/Person Presenting & 2 & 2 & 4 & 1 \\
\hline Leaving the Solution to the Children & 2 & 5 & 1 & 4 \\
\hline Questioning The Reason oftheBehaviour & 1 & 5 & 4 & 4 \\
\hline Total & 48 & 69 & 64 & 54 \\
\hline
\end{tabular}

It was detected that experimental teachers started using Awarding, Giving Role/Responsibility, Giving Explanation Related to Behaviour, Drawing Attention, Leaving the Solution to the Children, Questioning the Reason of the Behaviour more frequently while they used Time Out less frequently after training programme.

On the other hand, it was detected in the post-test that the teachers in control group preferred less Awarding, Time Out, Giving Role/Responsibility, Drawing Attention, and Example Case/Person Presenting while they preferred more to use Giving Explanation Related to Behaviour, and Leaving the Solution to the Children.

Finally, when the frequencies of supportive approach styles of the teachers in both groups were compared, the teachers in experiemental group expressed that they would use Awarding, Giving Role/Responsibility, Giving Explanation Related to Behaviour, Drawing Attention, Example Case/Person Presenting, Leaving the Solution to the Children, Questioning the Reason of the Behaviour, more frequently than the teachers in control group.

As a consequence, these findings show that the classroom management training programme improves the teacher's preferences related to supportive approach styles.

When the Preventive Approach Styles of the teachers in both groups were analized, five sub-themes and their frequencies were detected as shown in Table 7.

Table 7. The Findings Related to Preventive Approach Styles of Teachers

\begin{tabular}{lccccc}
\hline & Experimental & Experimental & \multicolumn{2}{c}{ Control } & \multicolumn{2}{c}{ Control } \\
Preventive Approach Styles & Pre-test & Post-test & Pre-test & Post-test \\
& (f) & (f) & (f) & (f) \\
\hline Defining Rule & 4 & 5 & 7 & 7
\end{tabular}




$\begin{array}{lcccc}\text { Using Reminders } & 4 & 9 & 7 & 6 \\ \text { Applying Preventing Intervention } & 3 & 4 & 3 & 2 \\ \text { Using Preventing Intervention Programme } & 1 & 30 & 0 & 0 \\ \text { Exibiting Consistant and Decisive Attitude } & 1 & 4 & 1 & 0 \\ \text { Total } & 13 & 52 & 18 & 15\end{array}$

The teachers in both groups stated that they would prefer the approaches of Defining Rule, Using Reminders, Applying Preventing Intervention, and Exibiting Consistent and Decisive Attitude. Moreover, the teachers in experimental group stated that they would prefer the approach of Using Preventing Intervention Programmes (Alternative Thinking Strategies Programme, I Can Problem Solve, Banking Time, Beyond Time out and Turtle Technique etc.).

Furthermore, it was seen that, the frequencies of all the sub-themes in experimental group increased seriously after the training.

The expression frequency of Using Reminders, Applying Preventing Intervention, Exibiting Consistent and Decisive Attitude in control group decreased but the frequency of the theme of Defining Rule remained the same in pre-test and post-test phases. Finally, when the frequencies of preventive approach styles of the teachers in both groups were compared, it was observed the experimental teacher's improved their thought or knowledge based on preventive intervention programs.

When the Restrictive Approach Styles of the teachers in both groups were analized, five sub-themes and their frequencies were detected as shown in Table 8.

Table 8. Findings Related to Restrictive Approach Styles of Teachers

\begin{tabular}{|c|c|c|c|c|}
\hline Restrictive Approach Style & $\begin{array}{l}\text { Experimental } \\
\text { Pre-test } \\
\text { (f) }\end{array}$ & $\begin{array}{l}\text { Experimental } \\
\text { Post-test } \\
\text { (f) }\end{array}$ & $\begin{array}{l}\text { Control } \\
\text { Pre-test } \\
\text { (f) }\end{array}$ & $\begin{array}{c}\text { Control } \\
\text { Post-test } \\
\text { (f) }\end{array}$ \\
\hline Punishment & 5 & 5 & 10 & 14 \\
\hline Verbal Warning & 2 & 1 & 3 & 4 \\
\hline Telling apology & 2 & 0 & 0 & 3 \\
\hline Directive/Exclusionary Time Out & 7 & 0 & 6 & 5 \\
\hline Total & 16 & 6 & 19 & 26 \\
\hline
\end{tabular}

Both groups expressed that they would prefer to use restrictive approach styles less than the other approach styles.

According to Table 8, expression frequency of Verbal Warning and Telling Apology in experimental group decreased but that of Using Punishment remained the same. It was observed in the table that the teachers in experimental group would not prefer to use Directive Time Out after the training programme. When total frequency of restrictive approach was analized, it was observed that the expression frequency of restrictive aproach styles in experimental group decreased after the training programme. The expression frequency of Punishment, Telling Apology and Verbal Warning in control group increased in post-test in comparison to pre-test. However, the expression frequency of Directive Exclusionary Time Out approach decreased. When the total expression frequency of restrictive aproaches in control group was analized, it was observed that the expression frequency of restrictive approach styles in control group increased in posttest phase rather than in pre-test phase. 
Güzeldere Aydin ,D. \& Ocak Karabay,Ş. (2020). Improvement of classroom management skills of teachers leads to creating positive classroom climate. International Journal of Educational Research

In the post-test phase, when the expression frequency of the restrictive approach styles after the training programme was analized, the expression frequency of Punishment, Verbal Warning, Telling Apology in experimental group were less than in control group as shown in Table 8.

The findings above show that classroom management training programme decreased the teachers' preferrences of restrictive approach styles. In another words, classroom management training programme ensures teachers to move away from negative approaches towards children.

\section{RESULT, DISCUSSION, AND SUGGESTIONS}

When the outcomes that the teachers in both groups were analized based on total score and five subdimensions (classroom structure and management, discipline, preventing misbehavior, emotional communication and support, and social awareness and problem solving) of TSRS, Classroom Management Training Programme has been detected as to have positive impact for the favor of the teachers in experimental group. The expreimental teachers performed better on maintaining routine and sustainability, applying rules consistently, using positive behaviour management strategies, being an emotional model (expressing and regulating emotion), presenting a proper guidance against problems, and preventing and regulating misbehaviours.

In this context, when the literature was analized, it was observed that multi-dimensional studies were conducted especially in the field of preventing intervention in order to eliminate the misbehaviours of the children, to create a positive atmosphere in classroom, and to enrich classroom management skills of teachers. When existing researches are analized, it is observed that the importance of education contents that will improve vocational skills of teachers in order to establish especially sensitive and responsive relationships and interactions is underlined (Burchinal, Peisner-Feinberg, Pianta, and Howes, 2002). It is also emphasized to create a positive atmosphere in classroom and to improve teachers' qualities against children's misbehaviours by way of more than one preventive intervention programme (Erwin, 1994; Morris, Millenky, Raver and Jones, 2013).

It is stated that these programmes improve the teachers' discipline techniques and classroom management skills to cope with the children who show misbehaviours (Anliak, 2004; Domitrovich et al., 2009; Shure, 2001). The classroom management in preschool period includes (Martin, Yin ve Baldwin, 1998) several contexts such as children's behaviours, educational processes and regulating social relations. It was observed that the researches in which the effect of the training programmes planned to improve classroom management approach styles of preschool teachers were verified were not at an adequate level.

When the findings in discipline, classroom structure and management and preventing misbehaviour sub-dimensions of TSRS were compared to the results of the researches in the literature, the teachers' preference of positive discipline strategies and avoidance of negative discipline strategies may help them to internalize these strategies and to increase pedegogic capabilities related to classroom structure and management as expected. Furthermore, it was observed that the experimental teachers approach in a more functional attitude in preventing misbehaviours, ensuring routines in classrooms, and applying rules consistently. This result is compatible with the the results of the studies made by applying Incredible Years Teacher Training Programme, which is used very commonly and is one of the preventive intervention programmes in classroom management. It was detected that positive behaviours of the teachers increased considerably (Baker-Henningham et al., 2009) while negative behaviours of the teachers decreased in the classrooms where the programme was applied. Other researches revealed that the programme contributed to the teachers' classroom management skills and education applications (Leckey et al., 2016; Marquez, Vincent, Marquez and Pennefarher, 2016). When emotional communication and support, and social awareness and problem solving sub-dimensions were analized, it was observed that there were positive changes in experimental teachers after the training in terms of being a role model for expressing and regulating feelings in classroom, presenting proper guidance against problems. The results of our research are similar to that of "The Foundation of Learning" intervention programme which included a series of classroom management strategies (Morris et al., 2013). The programme contributed to decrease the experimental group teachers' negative feelings and helped to increase their supportive and positive interactions in the classroom. In another research, the researchers determined positive changes in the the 
skills of the teachers, who applied Promoting Alternative Thinking Strategies / PATHS Preschool Curriculum, such as solving a problem when occured, preventing a problem from occuring, supporting children emotionally, and establishing discipline in a classroom (Arda ve Ocak, 2012). Thus, in this research, it was seen that the teachers could improve their skills of problem solving and emotion regulation, increase classroom management strategies. It is not a coincidence to find out the positive outcomes resulting after the teachers' professional lives were enriched in the dimensions of preventing intervention, social emotional learning and classroom management. Sutton, Mudrey-Camino and Knight (2009) states that the teachers reflect their positive and negative feelings to the interactions they established with children in the direction of their own social emotional skills. It is underlined that the teachers' supportive or punitive approach styles against to children's feelings has a binding effect in terms of not only interactions established with children but also being a model.

In this research, both the effect of Classroom Management Training Programme over teachers' teaching styles for classroom management and the effect of the same programme in the function of general classroom atmosphere were assessed. As a result of the observations in this research, it was detected that the classrooms of the teachers in experimental group were more cooperative, in an adoptive behaviours rather than disruptive behaviours and generally have a positive classroom atmosphere when compared to the classrooms of the other group. These results were also supported by the findings of 54 researches in which Classroom Management Intervention Programmes were applied. It was concluded that classroom management intervention programmes effect positively children's behavioural and social-emotional skills (Korpershoek et al., 2016). In this research, it was observed that adoptive behaviours and interest levels increased, maladaptive behaviours decreased in the classrooms in experimental group. In another research supporting the results of this research, it was also detected that Promoting Alternative Thinking Strategies / PATHS Preschool Curriculum decreased children's aggressive behaviours while improving social-emotional skills and focusing and effected positively children's adoptive levels and classroom atmopsphere (Arda, 2011). It is often stated that these programmes decreased maladjusted behaviours (Conduct Problems Prevention Research Group, 1999; Snell et al., 2014) and increased prosocial behaviours (Conduct Problems Prevention Research Group, 2010).

In this research, individual interviews in addition to observations were conducted in order to reveal the approach styles that the teachers would prefer to cope with maladjusted behaviours and to ensure classroom management. By way of these interviews, it was determined whether qualitative findings and quantitative findings gathered by means of observation support each other. Detailed data of teachers' preferences about how often and what kind of supportive, preventive and restrictive approaches were used were obtained. When research findings were assessed in this context, classroom management training programme contributed for the teachers to take a more active role in creating a positive classroom atmosphere and preventing misbehaviours. It also supported the teachers to gain a perspective for supportive and preventive approaches rather than restrictive approaches. When these findings were deeply analized, it was detected that the teachers in experimental groups expressed the supportive approaches such as rewarding, giving responsibility, drawing attention, inquiring the reason of the behaviour, leaving the solution to children during a problem more often than the teachers in control group. More important than that, it was also observed that the ratio of expressing preventive approache styles such as establishing rules, using reminders, implementing preventing intervention programme by experimental teachers increased in comparison to that of the teachers in control group.

Classroom management training programme reduced the experimental teachers' implementation of restrictive approach styles such as punishment, making children apologize, warning etc. in comparison to that of the teachers in control group. Also in quantitative findings collected by way of observation, which supports qualitative findings, it was observed that the teachers adopted positive and preventive classroom management approach such as consulting positive discipline strategies, implementing routines and rules consistently etc. for the sake of establishing discipline. 
Güzeldere Aydin ,D. \& Ocak Karabay,Ş. (2020). Improvement of classroom management skills of teachers leads to creating positive classroom climate. International Journal of Educational Research

Many approach styles for classroom management have been defined by the researchers (Karabay, 2017, s. 75). But, it is put forward that preventive focused classroom management approach style is more effective than reactive classroom management approach (Vitto, 2003). Researches emphasize that teachers have to motivate children in classroom, to make plans for their developments and interests, to show interest to children, to find with children solutions to problems by investigating the reason of the problem when it occurs (Pala, 2005), to take measures before the problems occur and to implement preventive strategies (Pala, 2005; Uğurlu et al., 2014).

When the result of this research are taken into consideration, it is thought that the practice based functional in-service trainings, which will ensure the teachers to be skillful in classroom management and consolidate child-teacher relationship, have to be presented to the teachers. Researches state that teacher candidates graduate without enough knowledge on classroom management (Allen, 2010; Drang, 2011). It is suggested that the content of the classroom management lesson has to include methods and strategies that will be implemented to children practically on a theoritical base and also be enriched with preventive intervention programmes that will support children's social and emotional development. The most important limitation of this study is that children's opinions are not consulted.In the future studies, it is recommended to implement preventive intervention programs such as ADS and BPÇ to support the social emotional development of children. Also, follow-up studies should be performed to obtain a long-term result.

\section{REFERENCES}

Allen, K. P. (2010). Classroom management, bullying, and teacher practices. The Professional Educator, 34(1).

Anlıak, Ş. (2004). Farklı eğitim yaklaşımları uygulayan okul öncesi eğitim kurumlarında kişiler arası bilişsel problem çözme becerisi programının etkisinin incelenmesi. (Yayımlanmış Doktora Tezi). Ege Üniversitesi/Sosyal Bilimler Enstitüsü, İzmir.

Arda, T. B. (2011). Alternatif düşünme stratejilerinin desteklenmesi programının okul öncesi çocuklarının sosyal becerileri üzerinde etkililiğinin değerlendirilmesi. (Yayımlanmış Yüksek Lisans Tezi). Ege Üniversitesi/Sosyal Bilimler Enstitüsü, İzmir.

Arda, T. B., \& Ocak, S. (2012). Social competence and promoting alternative thinking strategies-paths preschool curriculum. Educational Sciences: Theory and Practice, 12(4), 2691-2698.

Baker-Henningham, H., Walker, S., Powell, C. \& Gardner, M. J. (2009). A pilot study of the incredible years teacher training programme and a curriculum unit on social and emotional skills in community pre-schools in jamaica. Child: Care, Health and Development, 35(5), 624-631.

Borich, G. D. (2007). Effective teaching methods research based practice (6th ed.). Newjersey: Pearson Education Ltd.

Burchinal, M.R., Peisner-Feinberg, E., Pianta, R., \& Howes, C. (2002). Development of academic skills from preschool though second grade: family and classroom predictors of developmental trajectories. Journal of School Psychology, 40 (5), 415 - 436.

Büyüköztürk, Ş., Çakmak, E. K., Akgün, Ö. E., Karadeniz, Ş. \& Demirel, F. (2016). Bilimsel araştırma yöntemleri. Ankara: Pegem Akademi.

Cartleoge, G., \& Kourea, L. (2008). Culturally responsive classrooms for culturally diverse students with and at risk for disabilities. Exceptional Children, 74(3), 351-371.

Christensen, L. B., Johnson, R. B. ve Turner, L. A. (2015). Araştırma yöntemleri desen ve analiz. Ahmet Aypay (Çev. Ed.). Ankara: Anı. 
Conduct Problems Prevention Research Group (1999). Initial impact of the fast track prevention trial for conduct problems: Classroom effects. Journal of Consulting and Clinical Psychology, 67(5). 648-657.

Conduct Problems Prevention Research Group (2010). The effects of a multiyear universal social-emotional learning program: The role of student and school characteristics. Journal of Consulting and Clinical Psychology, 78(2): 156-168. doi:10.1037/a0018607.

Demirtaş, H. (2012). Sınıf yönetiminin temelleri. Hüseyin Kıran (Ed.). Etkili sınıf yönetimi içinde (s.1-34). Ankara: Anı Yayıncilik.

Drang, D.M. (2011). Preschool teachers' beliefs, knowledge, and practices related to classroom management. Doctoral Dissertation. Faculty of Graduate School of The University of Maryland College Park.

Domitrovich, C. E., Cortes, R., \& Greenberg, M. T. (2000). The teacher style rating scale technical report. Unpublished Manuscript. Pennsylvania State University.

Domitrovich, C. E., Gest, S. D., Gill, S., Bierman, K. L., Welsh, J. A., \& Jones, D. J. (2009). Fostering high quality teaching with an enriched curriculum and professional development: Head Start Redi. American Educational Research Journal, 46, 567-597.

Emmer, E. T. \& Stough, L. M. (2001). Classroom management: A critical part of educational psychology, with implications for teacher education. Educational Psychologist, 36(2), 103-112.

Erwin, P. G. (1994). Effectiveness of social skills training with children: A meta analitic study. Counselling Psychology Quarterly, 7 (3), 1-6.

Evertson, C. M., Emmer, E. T., \& Worsham M. E. (2003). Classroom management for elementary teachers. Boston: Pearson Education.

Gartrell, D. (2001). Replacing time-out part one - using guidence to build an encouraging classroom. Young Children, 8-16.

Harlan, J. C., \& Rowland S. T. (2002). Behavior management strategies for teachers. Charles C Thomas Publisher, LTD. Springfield, İllinois.

Hickey, G., McGilliwoy, S., Hyland, L., Leckey, Y., Kelly, P., Bywater, T., Comiskey, C., Lodge, A., Donnelly, M. ve O'Nell, D. (2015). Exploring the effects of a universal classroom management training programme on teacher and child behaviour: A group randomised controlled trial and cost analysis. Journal of Childhood Research. 15(2), 174-194. https://doi.org/10.1177/1476718X15579747

Howes, C., Fuligni, A.S., Hong, S.S., Huang, Y.D., Cinisomo, S.L. (2013). The preschool instructional context and child-teacher relationships. Early Education and Development, 24:3, 273-291.

Jones, V., \& Jones, L. (2004). Comprehensive classroom management creating communities of support and solving problems. BostonUnited States of America: Pearson Education.

Kaya, S., Lundeen, C. \& Wolfgang, H. C. (2010). Discipline orientations of pre-service teachers before and after student teaching. Teaching Education. 21(2), 157-169.

Korpershoek, H., Harms, T., De Boer, H., Van Kuijk, M., \& Doolaard, S. (2016). A meta-analysis of the effects of classroom management strategies and classroom management programs on students' academic, behavioral, emotional, and motivational outcomes. Review of Educational Research, 86(3), 643-680. doi: 10.3102/0034654315626799

Leckey, Y., Hyland, L., Hickey, G., Lodge, A., Kelly, P., Bywater, T., Comiskey, C., Donnelly, M., \& McGilloway, S. (2016). A Mixed-Methods Evaluation of the Longer-Term Implementation and Utility of a Teacher Classroom Management Training Programme in Irish Primary Schools. Irish Educational Studies, 35(1), 35-55. doi. 10.1080/03323315.2016.1147974.

Little, E., Hudson, A., \& Wilks, R. (2002). The efficacy of written teacher advice (tip sheets) for managing classroom behaviour problems. Educational Psychology, 22(3), 251-266. 
Martin, N., Yin. Z. and Baldwin, B. (1998). Classroom management training, class size and graduate study: do these variables impact teachers' beliefs regarding classroom management style? Paper Presented at The Annual Meeting of The American Educational Research Association (San Diego), CA.

Marquez, B., Vincent, C., Marquez, J., and Pennefarher, J. (2016). Opportunities and challenges in training elementary school teachers in classroom management: initial results from classroom management in action, an online professional development program. Jl. of Technology and Teacher Education, 24(1), 87-109.

Morris, P., Millenky M., Raver, C. C., and Jones S. M. (2013). Does a preschool social and emotional learning intervention pay off for classroom instruction and children's behavior and academic skills? Evidence from the foundations of learning project. Early Education and Development, 24, 1020-1042.

Ocak Karabay, Ş. (2017). Sınıf yönetimi modellerinde süreç ve değişimler. Sibel Yoleri (Ed.). Okul öncesi eğitimde sınıf yönetimi içinde (s.71-92). Ankara: Eğiten Kitap.

Pala, A. (2005). Sınıfta istenmeyen öğrenci davranışlarını önlemeye dönük disiplin modelleri. Manas Üniversitesi Sosyal Bilimler Dergisi, 13, 171-179.

Pianta, R. C. (2017). Çocuklar ve öğretmenler arasındaki ilişkilerin zenginleştirilmesi. Derya Şahin Ası ve Şakire Ocak Karabay (Çev.). Nobel Yayıncılık, Ankara.

Pianta, R.C. (1998). Enhancing relationships between children and teachers. Washington, DC: American Psychological Association.

Reddy, A. L., Fabiano, A. G., Dudek, M. C. ve Hsu, L. (2013). Instructional and behavior management practices implemented by elementary general education teachers. Journal of School Psychology, 51, 683-700.

Ritz, M., Noltemeyer, A., Davis, D., \& Green J. (2014). Behavior management in preschool classrooms: Insights revealed through systematic observation and interview. Psychology in the Schools, 51(2), 181-197. doi: 10.1002/pits.21744.

Rimm-Kaufman, S. E., Pianta, R. C., Early, D. M., Cox, M. J., Saluja, G., Bradley, R. H., \& Payne, C. (2002). Early behavioral attributes and teachers' sensitivity as predictors of competent behavior in the kindergarten classroom. Journal of Applied Developmental Psychology, 23, 451-470. doi:10.1016/S01933973(02)00128-4

Ross, C. P., Little, E. ve Kienhuis, M. (2008). Self-Reported and Actual Use Of Proactive and Reactive Classroom Management Strategies and Their Relationship With Teacher Stress and Student Behaviour. Educational Psychology, 28(6), 693-710. doi: 10.1080/01443410802206700.

Rydell, A. M. Ve Henricsson, L. (2004). Elementary school teachers' strategies to handle externalizing classroom behavior: a study of relations between perceived control, teacher orientation and strategy preferences. Scandinavian Journal of Psychology, 45, 93-102.

Shure, M. B. (2001). I can problem solve (An interpersonal cognitive problem-solving program) (ICPS) (2nd ed). Illinois: Research Press.

Sieberer-Nagler, K. (2016). Effective classroom-management \& positive teaching. English Language Teaching, 9(1), 163-172. doi:10.5539/elt.v9n1p163

Sabol T., J.,\& Pianta, R. C. (2012). Recent trends in research on teacher - child relationships. Attachment $\mathcal{E}$ Human Development, 14(3), 213-231.

Stough, L. M., Montague, M. L., Jo-Landmark, L., \& Williams-Diehm, K. (2015). Persistent classroom management training needs of experienced teachers. Journal of the Scholarship of Teaching and Learning, 15(5), 36-48. doi: 10.14434/josotl.v15i5.13784.

Snell, M. E., Voorhees, M. D., Walker, V. L., Berlin, R. A., Roorbach-Jamison, K., \& Stanton-Chapman, T. L. (2014). A demonstration of the universal problem-solving approach to address children's 
Güzeldere Aydin ,D. \& Ocak Karabay,Ş. (2020). Improvement of classroom management skills of teachers leads to creating positive classroom climate. International Journal of Educational Research

inappropriate behavior in head start classrooms. Topics in Early Childhood Special Education, 34(1), 415. doi: 10.1177/0271121413491836.

Sutton, R.E. (2004). Emotion regulation goals and strategies. Social Psychology of Education, 7, 379-398.

Sutton, R.E., Mudrey-Camino, R., \& Knight, C. C. (2009). Teacher's emotion regulation and classroom management. Theory into Practice, 48, 130-137.

Tillery, A. D, Varjas, K. Meyers, J., \& Collins, A. S. (2010). General education teachers' perceptions of behavior managements and intervention strategies. Journal of Positive Behavior Interventions, 12(2), 86-102.

Uğurlu, C., Doğan, S., Şöförtakımcı, G., Ay, D., \& Zorlu, H. (2014). Öğretmenlerin sınıf ortamında karşılaştıkları istenmeyen davranışlar ve bu davranışlarla baş etme stratejileri. Electronic Turkish Studies, 9(2), 577-602.

Vitto J. M. (2003). Relationship - driven classroom management strategies that promote student motivation. Corwin Press. Inc. Thousand Oaks, California.

Webster-Stratton, C., ve Herman, K. C. (2010). Disseminating incredible years series early intervention programs: Integrating and sustaining services between school and home. Psychology in the School, $47,36-54$.

Webster-Stratton, C., Reid, M. J., \& Hammond, M. (2004). Treating children with early-onset conduct problems: Intervention outcomes for parent, child, and teacher training. Journal of Clinical Child and Adolescent Psychology, 33(1), 105-124.

Westman, S., \& Bergmark V. (2014). A strengthened teaching mission in preschool: teachers' experiences, beliefs and strategies. International Journal of Early Years Education, 22(1), 73-88. doi: $10.1080 / 09669760.2013 .809653$ 